\title{
Assessing the Spectral Separability of Flue Cured Tobacco Varieties Established on Different Planting Dates and under Varying Fertilizer Management Levels
}

\author{
Ezekia Svotwa, ${ }^{1}$ Anxious J. Masuka, ${ }^{2}$ Barbara Maasdorp, ${ }^{3}$ and Amon Murwira ${ }^{4}$ \\ ${ }^{1}$ Kutsaga Research Station, P.O. Box 1909, Harare, Zimbabwe \\ ${ }^{2}$ Tobacco Research Board, Kutsaga Research Station, P.O. Box 1909, Harare, Zimbabwe \\ ${ }^{3}$ Department of Crop Science, University of Zimbabwe, Harare, Zimbabwe \\ ${ }^{4}$ Department of Geography and Environmental Science, University of Zimbabwe, Harare, Zimbabwe
}

Correspondence should be addressed to Ezekia Svotwa; esvotwa2@gmail.com

Received 30 September 2013; Revised 24 January 2014; Accepted 11 February 2014; Published 26 March 2014

Academic Editor: David Clay

Copyright (C) 2014 Ezekia Svotwa et al. This is an open access article distributed under the Creative Commons Attribution License, which permits unrestricted use, distribution, and reproduction in any medium, provided the original work is properly cited.

\begin{abstract}
The NDVI was used to discriminate tobacco variety, assess fertilizer levels, and determine the impact of planting date on separating crops. A split plot design with four planting dates, September, October, November, and December, as main plots, variety as subplot, and fertilizer treatments as sub-subplots was used. Radiometric measurements were taken from $5 \mathrm{~m} \times 5 \mathrm{~m}$ sampling plots, using a multispectral radiometer. The September, October, and November crops had significant variety $\mathrm{x}$ fertilizer treatment differences $(F<0.05)$ from the age of 10 weeks. T 66 and KRK26 varieties had similar $(F>0.05)$ NDVI values and these were greater $(F<0.5)$ than those for K E1. The $100 \%$ and the $150 \%$ fertilizer treatments were similar $(F>0.05)$ and both were greater $(F<0.05)$ than the $50 \%$ fertilizer treatments. All of the fertilizer and variety treatments at the December planting dates had similar reflectance characteristics $(P>0.05)$, which were lower $(P<0.05)$ than the September and October planting dates. The results showed that planting dates, varieties, and fertilizer levels could be distinguished using spectral data. Weeks 10-11 and 15 after the start of the experiment were optimal for separating the planting date effect.
\end{abstract}

\section{Background}

Flue cured tobacco variety, planting time, and fertilizer management can be direct sources of yield and quality differences. These variances affect plant canopy biophysical properties and chemical composition. Su et al. [1] reported the considerable effect that different nutrients and fertilizer rates have on plant leaf chemical composition. According to Mackown et al. [2] an understanding of the level of $\mathrm{N}$ fertilisation may be a suitable diagnostic test of crop $\mathrm{N}$ sufficiency that could be used for yield and quality predictions.

It is widely accepted that nitrogen $(\mathrm{N})$ plays a key role in the production of tobacco. Nitrogen is a constituent of chlorophyll, the green coloring matter in plants that plays a role in absorbing light for photosynthesis. The molecular structure of the chlorophyll incorporates a large proportion of total leaf nitrogen in the form of protein. Several studies have found that foliar chlorophyll concentration provides an accurate, indirect estimate of plant nutrient status [3].

Fertilizer management levels affect the crop canopy mineral composition and the way the canopy interacts with solar radiation. Interaction between light and intercepting molecules in the canopy results in scattering and absorption by the atomic bonds, electrons, or atoms in the molecule [4]. The wavelength at which the processes of absorption or reflection take place is highly specific for the atomic bonds and the molecular architecture of the intercepting target, making the identification of individual chemical components within the intercepting canopy possible [5].

Canopy reflectance of irradiance can be used as a rapid means of assessing the $\mathrm{N}$ status of the crop and can be a predictor of final yield [6]. The spectral absorbance properties of chemical components in plant leaves are manifested in the reflectance spectra of leaves [7]. This offers the opportunity of 
using measurements of reflected radiation as a nondestructive method for quantifying pigments as affected by level of crop management [3]. Similar cases of use of radiometric data for crop assessment and $\mathrm{N}$ estimation were reported over a wide range of crops $[8,9]$.

The spectral characteristics of vegetation vary with wavelength. Analysing vegetation using remotely sensed data requires knowledge of the structure and function of vegetation and its reflectance properties [10]. Leaf chlorophyll strongly absorbs radiation in the red and blue wavelengths but reflects in the green wavelength [11]. The internal structure of healthy leaves acts as a diffuse reflector of nearinfrared wavelengths. Measuring and monitoring the infrared reflectance can be useful in determining crop health [12].

Well managed crop canopies appear greenest and become red or yellow with decrease in chlorophyll content due to poor fertilisation [13]. Blackmer and Schepers [8] were able to separate $\mathrm{N}$ treatments using the near $550 \mathrm{~nm}$ reflectance measured on maize leaves detached from a field $\mathrm{N}$ fertilizer experiment and also found that nutrient stressed canopies had a lower spectral reflectance in the NIR and higher red wavebands when compared with unstressed canopies. Osborne et al. [14] and Graeff et al. [15, 16] could identify and quantify nutrient deficiencies by means of reflectance measurements based on selected stress specific wavelength ranges. Aase et al. [17] reported a relationship between wheat in-season dry matter and NIR/red ratios, suggesting that reflectance measurements could be used to estimate plant leaf dry matter.

The crop health and yield of tobacco depend on good agronomic practices which include among other things applying the recommended fertilizer rates and selection of appropriate planting dates [18]. Tobacco planting starts from the first day of September and to the end of the second week of December in Zimbabwe, depending on whether the farmer intends to irrigate the crop or rely on seasonal rainfall [19]. In Zimbabwe, the resource poor farmers resort to applying half the recommended fertilizer rates to save on their costs of production [19]. These practices have an impact on the health, physiological status, and final yield of the crop.

The Normalised Difference Vegetation Index (NDVI) is the most commonly used spectral index in assessing crop vigor, vegetation cover, and biomass production from multispectral satellite data $[20,21]$. The index is calculated using the formula NDVI = (NIR - Red $) /(\mathrm{NIR}+\mathrm{Red})$. As described by Jackson et al. [20], the index is considered a good indicator of the amount of vegetation and, hence, useful in distinguishing vegetation from soil. Benedetti and Rossini [22] used the NDVI in assessing wheat growth vigor and applied the information in estimating yield. Research at Kutsaga has established that the index is positively correlated with most biophysical characteristics of flue cured tobacco [23].

Monitoring of crop phenology by remote sensing is very important for many practical agronomic applications and notably for yield forecasting purposes [24]. Accurate analysis of temporal and spatial variations throughout the season can be used to interpret crop spectral response to agronomic management, as emphasized by Tucker et al. [25] . It is essential to quantify the relationship between spectral properties of tobacco and agronomic parameters in order to utilize the full potential of remote sensing for assessing crop condition and for forecasting yield. The use of effective remote sensing techniques in crop growth studies would eliminate the need for extensive field sampling by giving good nutrient adequacy detection capability [14].

This paper presents the results of an experiment, which was conducted to correlate the spectral indices with the agronomic variables of three flue cured tobacco varieties, four planting dates, and three fertilizer management levels. By measuring the energy that is reflected by a crop canopy surface over a variety of different wavelengths, it is hypothesized that spectral signatures for the varying fertilizer levels, varieties, and planting dates can be distinguished from the adjacent bare ground. It is also hypothesized that, from spectral characteristics of the canopies of the four planting dates, one can identify the most suitable temporal windows for meaningful measurements. This information could be very useful in estimating the area covered by each planting date treatment and in large area crop yield and quality predictions using remote sensing.

\section{Method}

2.1. Study Area. This experiment was conducted for three seasons at Kutsaga Research Station near Harare, Zimbabwe $\left(17^{\circ} 55^{\prime} \mathrm{S}, 31^{\circ} 08^{\prime} \mathrm{E}\right.$; Altitude $1480 \mathrm{~m}$ above sea level [26]), during summer and between 2010 and 2012. The experiment was carried out under irrigation on a sandy loam soil $(72.8 \%$ sand, $8.8 \%$ silt, and $18.4 \%$ clay). The long-term average annual rainfall for the station is $882 \mathrm{~mm}$. Before 2011 the research area had been planted to tobacco followed by four years of Chloris gayana $c v$. Katambora Rhodes grass [27]. The range average monthly temperature for the station is $8^{\circ} \mathrm{C}$.

A split plot design with four planting dates, September, October, November, and December, as main plots, variety as subplot, and fertilizer treatments as sub-subplots was used (Table 1). Three tobacco varieties, KRK26, T 66, and $\mathrm{K} \mathrm{E1}$, developed by Kutsaga Research Station were used, while three fertilizer management levels (50\%, 100\%, and $150 \%$ recommended) were applied by hand (Table 2 ). The recommended compound fertilizer rate from soil test results was $700 \mathrm{~kg} / \mathrm{ha}$, while that for ammonium nitrate $(34.5 \% \mathrm{~N})$ was $96 \mathrm{~kg} / \mathrm{ha}$ at 4 weeks after planting and $75 \mathrm{~kg} / \mathrm{ha}$ after topping.

An initial overhead preirrigation of $50-60 \mathrm{~mm}$ was applied at about 60 days before transplanting the tobacco. At transplanting, 4-5 liters of water was applied in each planting hole. A $15 \mathrm{~mm}$ settling in irrigation run was applied just after planting, followed by a 28-day stress period to promote root development, after which, $25-30 \mathrm{~mm}$ is applied to facilitate a nitrogenous fertilizer application.

The experimental plots were located on well-drained granitic sands and were low in available nitrogen, medium in available phosphorus, and high in available potassium content throughout the profile. During February of 2010 and 2011 the plots were disced after a three-year Katambora grass fallow period to incorporate grass. Agricultural lime was applied using recommendations given from soil test results 
TABLE 1: Soil analysis and fertilizer recommendations for experimental plots.

\begin{tabular}{|c|c|c|c|c|c|c|c|c|}
\hline \multirow{2}{*}{ Lab } & \multirow{2}{*}{ Your } & \multirow{2}{*}{ Crop } & \multicolumn{3}{|c|}{$\mathrm{N}: \mathrm{P}: \mathrm{K}$ fertilizers } & \multirow{2}{*}{$\begin{array}{c}\text { Required nutrients } \\
\text { Rate }(\mathrm{kg} / \mathrm{ha})\end{array}$} & \multirow{2}{*}{$\begin{array}{c}\text { Suggested fertilizer } \\
\text { Application top dressing }\end{array}$} & \multirow{2}{*}{ Lime $(\mathrm{kg} / \mathrm{ha})$} \\
\hline & & & $\mathrm{N}$ & $\mathrm{P}$ & $\mathrm{K}$ & & & \\
\hline 113315 & Land block 1 & Tobacco & $* * *$ & $140-160$ & $70-100$ & $*: 20: 17$ & 800 (i.e, 2 cup no. $22 /$ plant) & 760 \\
\hline 113316 & Land block 2 & Tobacco & $* * *$ & $100-120$ & $70-100$ & $*: 20: 17$ & 600 (i.e, cup no. $(30+5) /$ plant $)$ & NIL \\
\hline 113317 & Land block 3 & Tobacco & $* * *$ & $100-120$ & $70-100$ & $*: 20: 17$ & 600 (i.e, cup no. $(30+5) /$ plant $)$ & 600 \\
\hline 113301 & Land block 4 & Tobacco & $* * *$ & $80-100$ & $70-100$ & $*: 20: 17$ & 500 (i.e, cup no. 30/plant) & 600 \\
\hline
\end{tabular}

TABLE 2: Variety and fertilizer treatments.

\begin{tabular}{lc}
\hline Variety & Fertilizer \\
\hline KRK26 & $50 \%$ fertilizer \\
KRK26 & $100 \%$ fertilizer \\
KRK26 & $150 \%$ fertilizer \\
T 66 & $50 \%$ fertilizer \\
T 66 & $100 \%$ fertilizer \\
T 66 & $150 \%$ fertilizer \\
K E1 & $50 \%$ fertilizer \\
K E1 & $100 \%$ fertilizer \\
K E1 & $150 \%$ fertilizer \\
\hline
\end{tabular}

to raise the soil $\mathrm{pH}$ from 5.3 to 6.3 levels optimum for tobacco production (Table 1). For the three years preceding the 2010 experiments, the sites were under Katambora grass to control nematodes. Recommended management practices were followed [26] except for $\mathrm{N}: \mathrm{P}: \mathrm{K}$ levels and planting times, which were treatments in the experiment. Fertilizer and lime application was done using the results of the soil analysis provided by the soil chemistry laboratory at Kutsaga (Table 1).

2.2. Fertilizer Treatments. The N : P : K treatments were handapplied in bands, about $10 \mathrm{~cm}$ deep and $30 \mathrm{~cm}$ to each side of a row at planting, while $\mathrm{N}$ treatments were applied at about 4 weeks after transplanting after topping and at 6 weeks after planting.

2.3. Procedure. Radiometric measurements were taken on $5 \mathrm{~m} \times 5 \mathrm{~m}$ square sampling plots, using a hand-held multispectral radiometer (Cropscan MSR-5, 450-1750 nm), with the FOV centering over rows. Each sampling plot consisted of 5 rows, each with 32 plants spaced at $56 \mathrm{~cm}$. The interrow distance was $1.2 \mathrm{~m}$. Normalised Difference Vegetation Index (NDVI) was calculated from the spectral bands obtained in Channels 3 and 4 which correspond to the red (630-690 nm) and near-infrared (nir) $(60-900 \mathrm{~nm})$ regions of the MSR 5, respectively, using the following formula:

$$
\mathrm{NDVI}=\frac{\text { nir }- \text { red }}{\text { nir }+ \text { red }}
$$

Fasheun and Balogun [28] suggested that NDVI was sensitive to the biochemical properties of leaf and phenological stage of crop, respectively.

The multispectral radiometer (MRS 5) was positioned facing vertically downward at $1 \mathrm{~m}$ above crop canopies, and measurements were taken around solar noon to minimize the effect of diurnal changes in solar zenith angle. In total, 10 measurements were taken per sampling unit and reflectance measurements were averaged for each sampling plot to estimate a single reflectance value. Three-dimensional positions, latitude, longitude, and altitude, for the whole experimental area and for each treatment plot were taken using a Garmin Personal Navigator (GPS V) to enable repeated sampling at the same location. The average NDVI data for the two seasons were used for the analysis.

2.4. Data Analysis. NDVI data was analysed by analysis of variance and statistically significant treatment effects were separated using least significant differences (LSD). The data was analysed using the Genstat 9.2 statistical package at 5\% level of significance. Student's $t$-test calculations were done to compare the planting date effect and graphs were plotted using Excel 2007.

\section{Results}

The September planted crop's NDVI reached a peak of $0.7-0.85$ at $10-13$ weeks after planting (Table 3). During the juvenile stages, all the variety fertilizer management treatments were statistically similar $(P>0.05)$. There were significant $(P<0.05)$ fertilizer level differences in the NDVI starting from the age of 10 weeks after planting. At peak the NDVIs for $100 \%$ and the $150 \%$ fertilizer levels were statistically similar and were both significantly greater than the 50\% fertilizer treatments. The NDVI for the three varieties were also significantly different $(P<0.05)$ from 7 weeks after planting when canopy reflectance measurements started. The varieties T 66 and KRK26 NDVIs were statistically similar $(P>0.05)$ and were significantly greater than that for K E1 treatments. There was no variety $\mathrm{x}$ fertilizer level interaction effect $(P>0.05)$. This trend was maintained beyond the peak stage and as the NDVI fell to the lowest levels at 16-17 weeks of age.

The NDVI for all the treatments in the October planted crop rose sharply from week 6 after planting to peak at approximately 9 weeks after planting (Table 4 ). Beyond the peak, the NDVI also fell gently to reach the minimum at 13 weeks of age. Like the September planting, all the treatments had similar $(F>0.05)$ NDVI from 6 weeks after planting until the age of 10 weeks, when a peak NDVI was attained. The $100 \%$ and the $150 \%$ fertilizer levels of T 66 and KRK26 were also statistically similar $(P>0.05)$ and were significantly greater than both their $50 \%$ fertilizer and all 
TABLE 3: The NDVI temporal profiles for the September 15 planted crop.

\begin{tabular}{|c|c|c|c|c|c|c|c|c|c|c|c|}
\hline \multirow{2}{*}{ Variety } & \multirow{2}{*}{ Fertilizer } & \multicolumn{10}{|c|}{ Weeks after planting } \\
\hline & & 7 & 8 & 10 & 12 & 13 & 15 & 17 & 19 & 21 & 22 \\
\hline KRK26 & $50 \%$ fertilizer & 0.65 & 0.79 & 0.79 & 0.78 & 0.70 & 0.54 & 0.41 & 0.32 & 0.37 & 0.50 \\
\hline KRK26 & $100 \%$ fertilizer & 0.69 & 0.82 & 0.83 & 0.82 & 0.70 & 0.55 & 0.41 & 0.29 & 0.34 & 0.43 \\
\hline KRK26 & $150 \%$ fertilizer & 0.69 & 0.82 & 0.85 & 0.82 & 0.76 & 0.61 & 0.48 & 0.40 & 0.35 & 0.43 \\
\hline Т 66 & $50 \%$ fertilizer & 0.64 & 0.80 & 0.79 & 0.78 & 0.68 & 0.54 & 0.37 & 0.29 & 0.40 & 0.50 \\
\hline T 66 & $100 \%$ fertilizer & 0.65 & 0.82 & 0.85 & 0.83 & 0.75 & 0.67 & 0.52 & 0.41 & 0.46 & 0.40 \\
\hline Т 66 & $150 \%$ fertilizer & 0.65 & 0.82 & 0.84 & 0.85 & 0.79 & 0.70 & 0.60 & 0.34 & 0.39 & 0.47 \\
\hline K E1 & $50 \%$ fertilizer & 0.61 & 0.75 & 0.76 & 0.75 & 0.65 & 0.52 & 0.23 & 0.27 & 0.34 & 0.58 \\
\hline K E1 & $100 \%$ fertilizer & 0.61 & 0.73 & 0.73 & 0.75 & 0.63 & 0.53 & 0.30 & 0.30 & 0.42 & 0.59 \\
\hline K E1 & $150 \%$ fertilizer & 0.63 & 0.76 & 0.78 & 0.80 & 0.70 & 0.65 & 0.53 & 0.32 & 0.39 & 0.53 \\
\hline \multirow{3}{*}{ Variety $*$ fertilizer } & F-Probability & 0.84 & 0.62 & 0.01 & 0.26 & 0.10 & 0.33 & 0.11 & 0.09 & 0.21 & 0.32 \\
\hline & S.E.D & 0.03 & 0.02 & 0.02 & 0.02 & 0.02 & 0.05 & 0.06 & 0.05 & 0.04 & 0.05 \\
\hline & L.S.D & 0.07 & 0.05 & 0.03 & 0.04 & 0.05 & 0.10 & 0.13 & 0.10 & 0.08 & 0.10 \\
\hline \multirow{6}{*}{ Fertilizer } & $50 \%$ fertilizer & 0.63 & 0.78 & 0.78 & 0.77 & 0.67 & 0.53 & 0.33 & 0.29 & 0.37 & 0.53 \\
\hline & $100 \%$ fertilizer & 0.65 & 0.79 & 0.80 & 0.80 & 0.70 & 0.58 & 0.41 & 0.33 & 0.41 & 0.48 \\
\hline & $150 \%$ fertilizer & 0.65 & 0.80 & 0.82 & 0.82 & 0.75 & 0.65 & 0.54 & 0.35 & 0.38 & 0.48 \\
\hline & F-Probability & 0.51 & 0.32 & 0.001 & 0.004 & $<0.001$ & 0.002 & $<0.001$ & 0.10 & 0.15 & 0.15 \\
\hline & S.E.D & 0.02 & 0.01 & 0.009 & 0.01 & 0.01 & 0.03 & 0.04 & 0.03 & 0.02 & 0.03 \\
\hline & L.S.D & 0.04 & 0.03 & 0.019 & 0.02 & 0.03 & 0.06 & 0.08 & 0.06 & 0.04 & 0.06 \\
\hline \multirow{6}{*}{ Variety } & K RK26 & 0.68 & 0.81 & 0.82 & 0.81 & 0.72 & 0.57 & 0.43 & 0.34 & 0.35 & 0.45 \\
\hline & Т 66 & 0.64 & 0.81 & 0.83 & 0.82 & 0.74 & 0.64 & 0.50 & 0.35 & 0.42 & 0.46 \\
\hline & K E1 & 0.62 & 0.75 & 0.76 & 0.77 & 0.66 & 0.56 & 0.35 & 0.29 & 0.38 & 0.57 \\
\hline & F-Probability & 0.01 & $<0.001$ & $<0.001$ & 0.002 & $<0.001$ & 0.03 & 0.004 & 0.13 & 0.03 & 0.004 \\
\hline & S.E.D & 0.02 & 0.01 & 0.009 & 0.01 & 0.01 & 0.03 & 0.04 & 0.03 & 0.02 & 0.03 \\
\hline & L.S.D & 0.04 & 0.03 & 0.019 & 0.02 & 0.03 & 0.06 & 0.08 & 0.06 & 0.04 & 0.06 \\
\hline
\end{tabular}

the K E1 treatments. The varietal NDVI differences were less pronounced when compared with those for the September crop. Like the September crop there was no interaction effect observed $(P>0.05)$.

The November fertilizer treatment effect also followed a comparable trend to the September and October plantings (Table 5). There was a gentler decline of the NDVI values after the peak stage (9-10 weeks after planting). The minimum 0.50.6 was attained at 15 weeks after planting. From the crop age of 12 weeks after planting, the varieties showed significant $(P<0.05)$ NDVI differences. The variety $\mathrm{x}$ fertilizer level interaction was also absent.

The December crop peak was attained at 8 weeks after planting and was maintained to the age of 10 weeks after planting (Table 6$)$. There were no significant $(F<0.05)$ treatment differences from the first sampling to the end of reaping in week 13 after planting.

The NDVI values for the September and October crops were similar $(t>0.05)$ and both were significantly greater than those for the November and the December crops (Figure 1). There was a general fall of the NDVI with later plantings. At all fertilizer levels, K E1 had the highest NDVI in the October planted crop.

The September crop had the longest field life span of 22 weeks, as compared to the 17,15 , and 12 weeks for the October,

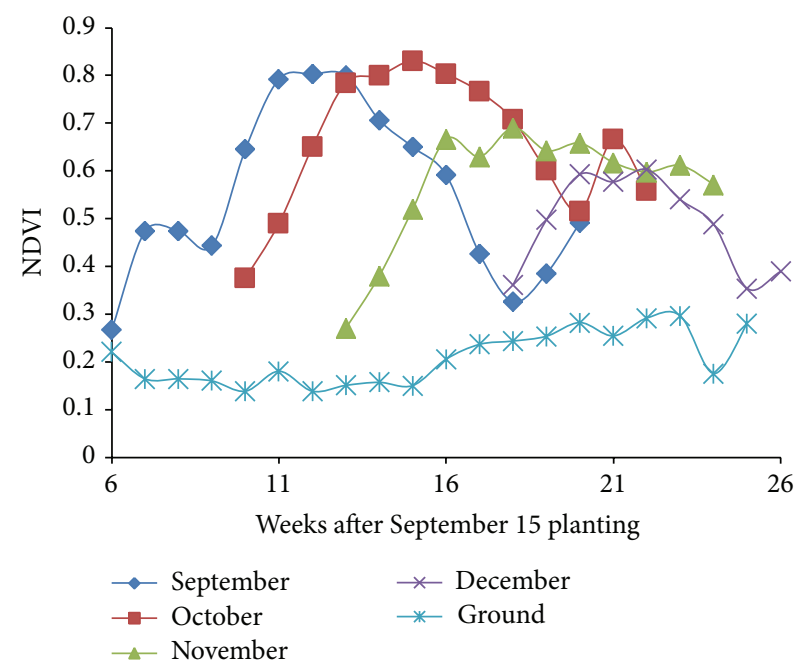

FIGURE 1: NDVI profiles for the September, October, November, and December crops.

November, and December crops, respectively (Figure 1). The September planted crop could be separated from later plantings in the first 9 weeks of establishment. Between 6 and 16 weeks of the tobacco growing season, the September, 
TABLE 4: The NDVI temporal profiles for the October 15 planted crop.

\begin{tabular}{|c|c|c|c|c|c|c|c|c|c|c|c|}
\hline \multirow{2}{*}{ Variety } & \multirow{2}{*}{ Fertilizer } & \multicolumn{10}{|c|}{ Weeks after planting } \\
\hline & & 5 & 6 & 8 & 10 & 11 & 12 & 14 & 15 & 16 & 17 \\
\hline KRK26 & $50 \%$ fertilizer & 0.36 & 0.80 & 0.74 & 0.80 & 0.77 & 0.72 & 0.51 & 0.45 & 0.63 & 0.52 \\
\hline KRK26 & $100 \%$ fertilizer & 0.37 & 0.82 & 0.78 & 0.82 & 0.78 & 0.70 & 0.60 & 0.51 & 0.74 & 0.57 \\
\hline KRK26 & $150 \%$ fertilizer & 0.31 & 0.83 & 0.78 & 0.83 & 0.81 & 0.78 & 0.62 & 0.49 & 0.66 & 0.55 \\
\hline Т 66 & $50 \%$ fertilizer & 0.40 & 0.81 & 0.77 & 0.81 & 0.77 & 0.72 & 0.57 & 0.53 & 0.66 & 0.55 \\
\hline Т 66 & $100 \%$ fertilizer & 0.36 & 0.84 & 0.77 & 0.84 & 0.83 & 0.80 & 0.68 & 0.54 & 0.66 & 0.55 \\
\hline Т 66 & $150 \%$ fertilizer & 0.37 & 0.85 & 0.80 & 0.85 & 0.83 & 0.82 & 0.56 & 0.54 & 0.67 & 0.58 \\
\hline K E1 & $50 \%$ fertilizer & 0.40 & 0.82 & 0.78 & 0.82 & 0.78 & 0.75 & 0.54 & 0.52 & 0.57 & 0.58 \\
\hline K E1 & $100 \%$ fertilizer & 0.40 & 0.85 & 0.80 & 0.85 & 0.82 & 0.81 & 0.60 & 0.50 & 0.70 & 0.54 \\
\hline K E1 & $150 \%$ fertilizer & 0.41 & 0.86 & 0.81 & 0.86 & 0.82 & 0.82 & 0.71 & 0.52 & 0.65 & 0.56 \\
\hline \multirow{3}{*}{$\mathrm{V} * \mathrm{~F}$} & F-Probability & 0.22 & 0.99 & 0.88 & 0.99 & 0.83 & 0.11 & 0.45 & 0.87 & 0.28 & 0.31 \\
\hline & S.E.D & 0.03 & 0.02 & 0.03 & 0.02 & 0.02 & 0.03 & 0.08 & 0.05 & 0.04 & 0.03 \\
\hline & L.S.D & 0.06 & 0.04 & 0.06 & 0.04 & 0.05 & 0.06 & 0.19 & 0.11 & 0.09 & 0.06 \\
\hline \multirow{6}{*}{ Fertilizer } & $50 \%$ fertilizer & 0.39 & 0.81 & 0.76 & 0.81 & 0.77 & 0.73 & 0.54 & 0.50 & 0.62 & 0.55 \\
\hline & $100 \%$ fertilizer & 0.38 & 0.84 & 0.79 & 0.84 & 0.80 & 0.77 & 0.63 & 0.51 & 0.70 & 0.56 \\
\hline & $150 \%$ fertilizer & 0.36 & 0.85 & 0.79 & 0.85 & 0.82 & 0.80 & 0.63 & 0.52 & 0.66 & 0.57 \\
\hline & F-Probability & 0.27 & 0.007 & 0.15 & 0.007 & 0.005 & $<0.001$ & 0.15 & 0.84 & 0.02 & 0.54 \\
\hline & S.E.D & 0.02 & 0.01 & 0.02 & 0.01 & 0.01 & 0.02 & 0.05 & 0.03 & 0.03 & 0.02 \\
\hline & L.S.D & 0.03 & 0.02 & 0.03 & 0.02 & 0.03 & 0.03 & 0.11 & 0.06 & 0.05 & 0.03 \\
\hline \multirow{6}{*}{ Variety } & KRK26 & 0.35 & 0.81 & 0.77 & 0.81 & 0.79 & 0.73 & 0.58 & 0.48 & 0.68 & 0.55 \\
\hline & T 66 & 0.38 & 0.83 & 0.78 & 0.83 & 0.81 & 0.78 & 0.60 & 0.54 & 0.66 & 0.56 \\
\hline & K E1 & 0.40 & 0.84 & 0.80 & 0.84 & 0.81 & 0.79 & 0.62 & 0.51 & 0.64 & 0.56 \\
\hline & F-Probability & 0.008 & 0.04 & 0.23 & 0.04 & 0.19 & 0.005 & 0.71 & 0.23 & 0.47 & 0.61 \\
\hline & S.E.D & 0.02 & 0.01 & 0.02 & 0.01 & 0.01 & 0.02 & 0.05 & 0.03 & 0.03 & 0.02 \\
\hline & L.S.D & 0.03 & 0.02 & 0.03 & 0.02 & 0.03 & 0.03 & 0.11 & 0.06 & 0.05 & 0.03 \\
\hline
\end{tabular}

October, and November crops could be separated because of their significant $(t<0.05)$ average NDVI differences. This was well before the December crop was established. The September crop declined at 15 weeks after planting, when the October crop was at peak. Only the December planted crop was actively growing in the field beyond 24 weeks after the start of the experiment. A summary of the approximate times for collecting reflectance data for separating the crops is presented in Table 7 .

\section{Discussions}

The general NDVI profile followed the same pattern as the leaf area index [25]. Similar to the findings of Peng et al. [29], the spectral characteristics of tobacco in the luxuriant growth stages between 0 and 10 weeks after planting were very similar, making it difficult to separate variety and fertilizer effect using a single-phase remote sensing image.

The September and October crops had higher average reflectance values than the November and December crops. This could have resulted from the dry conditions under which these crops are established. The crops are generally subjected to 4-6 weeks of dry conditions before irrigation is applied or rains received [26]. The moderate stress is considered beneficial to the tobacco plants, as deeper root development is encouraged in preparation for the rapid growth phase. The additional root development results in increases in yield and quality of the cured leaf [18]. In addition, the stimulation of root development subsequently promotes the attainment of desirable chemical composition.

Generally, periods of severe water stress, however, can cause a negative spectral response as argued by NegeswaraRao et al. [30] and in the NDVI profiles. Such responses were evidenced by the negative oscillations during weeks 9 and 10 of the September planted crop. The general decline of the NDVI with late planting was similar to the documented response of tobacco yield to planting time [26], thus showing the potential for NDVI to be used in developing yield forecasting models [31].

The separation of flue cured varieties and fertilizer levels using canopy reflectance could be done at the age of at least 10 weeks after planting when NDVI differences among these became significant. The 10 -week stage coincided with the period of intense reaping for most flue cured tobacco varieties. At this stage, the potential of the different crops in the field, as determined by variety and fertilizer management, could easily be detected and considered in overall yield estimation.

The higher NDVI for both 100 and $150 \%$ fertilizer level treatments for T 66 and KRK26 could be an indication of 
TABLE 5: The NDVI temporal profiles for the November 15 planted crop.

\begin{tabular}{|c|c|c|c|c|c|c|c|c|c|c|c|}
\hline \multirow{2}{*}{ Variety } & \multirow{2}{*}{ Fertilizer } & \multicolumn{10}{|c|}{ Weeks after planting } \\
\hline & & 5 & 7 & 8 & 10 & 11 & 12 & 13 & 14 & 15 & 16 \\
\hline KRK26 & $50 \%$ fertilizer & 0.25 & 0.49 & 0.62 & 0.62 & 0.57 & 0.57 & 0.54 & 0.54 & 0.59 & 0.59 \\
\hline KRK26 & $100 \%$ fertilizer & 0.27 & 0.51 & 0.64 & 0.70 & 0.63 & 0.62 & 0.58 & 0.58 & 0.58 & 0.54 \\
\hline KRK26 & $150 \%$ fertilizer & 0.24 & 0.57 & 0.64 & 0.74 & 0.68 & 0.68 & 0.64 & 0.64 & 0.60 & 0.54 \\
\hline Т 66 & $50 \%$ fertilizer & 0.31 & 0.51 & 0.67 & 0.67 & 0.61 & 0.61 & 0.59 & 0.59 & 0.62 & 0.58 \\
\hline Т 66 & $100 \%$ fertilizer & 0.30 & 0.55 & 0.71 & 0.70 & 0.65 & 0.68 & 0.67 & 0.67 & 0.66 & 0.57 \\
\hline T 66 & $150 \%$ fertilizer & 0.27 & 0.52 & 0.69 & 0.75 & 0.73 & 0.75 & 0.69 & 0.69 & 0.67 & 0.61 \\
\hline K E1 & $50 \%$ fertilizer & 0.25 & 0.46 & 0.63 & 0.56 & 0.54 & 0.56 & 0.56 & 0.56 & 0.60 & 0.59 \\
\hline K E1 & $100 \%$ fertilizer & 0.28 & 0.55 & 0.68 & 0.72 & 0.67 & 0.69 & 0.59 & 0.59 & 0.59 & 0.54 \\
\hline K E1 & $150 \%$ fertilizer & 0.27 & 0.51 & 0.73 & 0.77 & 0.71 & 0.76 & 0.69 & 0.69 & 0.59 & 0.59 \\
\hline \multirow{3}{*}{ VAR $*$ fertilizer } & F-Probability & 0.65 & 0.71 & 0.72 & 0.25 & 0.52 & 0.34 & 0.58 & 0.58 & 0.74 & 0.49 \\
\hline & S.E.D & 0.03 & 0.06 & 0.05 & 0.04 & 0.04 & 0.03 & 0.03 & 0.03 & 0.04 & 0.03 \\
\hline & L.S.D & 0.06 & 0.13 & 0.11 & 0.09 & 0.09 & 0.07 & 0.07 & 0.07 & 0.08 & 0.07 \\
\hline \multirow{6}{*}{ Fertilizer } & $50 \%$ fertilizer & 0.27 & 0.49 & 0.64 & 0.61 & 0.57 & 0.58 & 0.56 & 0.56 & 0.60 & 0.59 \\
\hline & $100 \%$ fertilizer & 0.28 & 0.54 & 0.68 & 0.71 & 0.65 & 0.66 & 0.61 & 0.61 & 0.61 & 0.55 \\
\hline & $150 \%$ fertilizer & 0.26 & 0.54 & 0.69 & 0.75 & 0.71 & 0.73 & 0.67 & 0.67 & 0.62 & 0.58 \\
\hline & F-Probability & 0.46 & 0.28 & 0.29 & $<0.001$ & $<0.001$ & $<0.001$ & $<0.001$ & $<0.001$ & 0.62 & 0.14 \\
\hline & S.E.D & 0.02 & 0.03 & 0.03 & 0.02 & 0.02 & 0.02 & 0.02 & 0.02 & 0.02 & 0.02 \\
\hline & L.S.D & 0.04 & 0.07 & 0.06 & 0.05 & 0.05 & 0.04 & 0.04 & 0.04 & 0.05 & 0.04 \\
\hline \multirow{8}{*}{ Variety } & & & & & & & & & 0.58 & 0.59 & 0.56 \\
\hline & KRK26 & 0.25 & 0.52 & 0.63 & 0.69 & 0.63 & 0.62 & 0.58 & 0.65 & 0.65 & 0.58 \\
\hline & Т 66 & 0.29 & 0.53 & 0.69 & 0.71 & 0.66 & 0.68 & 0.66 & 0.61 & 0.59 & 0.57 \\
\hline & K E1 & 0.27 & 0.51 & 0.68 & 0.68 & 0.64 & 0.67 & 0.61 & & & \\
\hline & & & & & & & & & 0.01 & 0.03 & 0.35 \\
\hline & F-Probability & 0.10 & 0.83 & 0.12 & 0.61 & 0.31 & 0.03 & 0.01 & 0.02 & 0.02 & 0.02 \\
\hline & S.E.D & 0.02 & 0.03 & 0.03 & 0.02 & 0.02 & 0.02 & 0.02 & 0.04 & 0.05 & 0.04 \\
\hline & L.S.D & 0.04 & 0.07 & 0.06 & 0.05 & 0.05 & 0.04 & 0.04 & & & \\
\hline
\end{tabular}

higher yield potential for these treatments. According to Jiang et al. [32], the NDVI reflects the growing status of green vegetation, thus making the task of crop monitoring and crop yield estimation by remote sensing realizable. The different rates of fall of NDVI after the peak could be due to fertilizer $\mathrm{x}$ variety treatment related ripening rates [32].

A long life span in the field is important in increasing the crop leaf area duration (LAD), which is very essential for the crop to complete the development of sinks $[33,34]$. In the experiment, crop life span generally decreased with late planting in the experiment.

The similarity of average NDVI for the three varieties in September could be an indication of equal yield potential under such growing conditions, making it possible to estimate combined area and yield forecast for the three. The difference between the bare ground and crop canopy reflectance could be directly related to biomass and should be considered in yield forecasting models.

The NDVI profiles for the four planting dates could be used to select window periods at which the singlephase NDVIs were significantly different. This would enable separate monitoring of crops for specific planting dates.
As Jiang et al. [35] pointed out, crop area estimation for the different planting dates could be realised using remote sensing techniques on the basis of time serial NDVI data together with agriculture calendars.

\section{Conclusions}

Tobacco varieties and fertilizer management effect could be distinguished using spectral data after the attainment of peak canopy reflectance. Crops planted on different planting dates had different temporal profiles. Periods where these were significantly different could be used in calculating crop area forecasts.

Varieties T 66 and KRK26 could not be distinguished by both single-day remote sensing imagery and temporal NDVI profile in the field while KE 1 could be separated from at least 10 weeks after planting. Under-fertilized tobacco could be distinguished in the field by its lower NDVI than the optimally and over-fertilized crop from at least 10 weeks after planting.

The results of this study indicated that the second to last week of November and the period between late January and late February to early March were the optimal times for 
TABle 6: The NDVI temporal profiles for the December 15 planted crop.

\begin{tabular}{|c|c|c|c|c|c|c|c|c|c|}
\hline \multirow{2}{*}{ Variety } & \multirow{2}{*}{ Fertilizer } & \multicolumn{8}{|c|}{ Weeks after planting } \\
\hline & & 5 & 6 & 7 & 8 & 9 & 11 & 12 & 13 \\
\hline KRK26 & $50 \%$ fertilizer & 0.34 & 0.43 & 0.54 & 0.63 & 0.51 & 0.48 & 0.40 & 0.38 \\
\hline KRK26 & $100 \%$ fertilizer & 0.44 & 0.61 & 0.67 & 0.61 & 0.64 & 0.51 & 0.31 & 0.36 \\
\hline KRK26 & $150 \%$ fertilizer & 0.37 & 0.47 & 0.57 & 0.53 & 0.55 & 0.45 & 0.40 & 0.39 \\
\hline Т 66 & $50 \%$ fertilizer & 0.39 & 0.51 & 0.61 & 0.58 & 0.59 & 0.51 & 0.35 & 0.36 \\
\hline Т 66 & $100 \%$ fertilizer & 0.39 & 0.52 & 0.61 & 0.51 & 0.63 & 0.49 & 0.37 & 0.41 \\
\hline Т 66 & $150 \%$ fertilizer & 0.35 & 0.54 & 0.61 & 0.66 & 0.68 & 0.53 & 0.38 & 0.40 \\
\hline K E1 & $50 \%$ fertilizer & 0.28 & 0.39 & 0.50 & 0.49 & 0.56 & 0.48 & 0.34 & 0.39 \\
\hline K E1 & $100 \%$ fertilizer & 0.39 & 0.51 & 0.63 & 0.60 & 0.61 & 0.53 & 0.36 & 0.40 \\
\hline K E1 & $150 \%$ fertilizer & 0.31 & 0.50 & 0.58 & 0.58 & 0.66 & 0.56 & 0.27 & 0.41 \\
\hline \multirow{3}{*}{$\mathrm{V} * \mathrm{~F}$} & $F$-Probability & 0.53 & 0.47 & 0.45 & 0.04 & 0.51 & 0.30 & 0.17 & 0.74 \\
\hline & S.E.D & 0.05 & 0.07 & 0.06 & 0.06 & 0.06 & 0.04 & 0.05 & 0.03 \\
\hline & L.S.D & 0.11 & 0.16 & 0.12 & 0.13 & 0.13 & 0.09 & 0.11 & 0.07 \\
\hline \multirow{6}{*}{ Fertilizer } & $50 \%$ fertilizer & 0.34 & 0.44 & 0.55 & 0.57 & 0.55 & 0.49 & 0.36 & 0.38 \\
\hline & $100 \%$ fertilizer & 0.41 & 0.55 & 0.64 & 0.57 & 0.63 & 0.51 & 0.35 & 0.39 \\
\hline & $150 \%$ fertilizer & 0.34 & 0.50 & 0.59 & 0.59 & 0.63 & 0.52 & 0.35 & 0.40 \\
\hline & F-Probability & 0.05 & 0.08 & 0.05 & 0.79 & 0.07 & 0.55 & 0.79 & 0.47 \\
\hline & S.E.D & 0.03 & 0.04 & 0.03 & 0.04 & 0.04 & 0.03 & 0.03 & 0.02 \\
\hline & L.S.D & 0.06 & 0.09 & 0.07 & 0.07 & 0.07 & 0.05 & 0.06 & 0.04 \\
\hline \multirow{6}{*}{ Variety } & KRK26 & 0.38 & 0.51 & 0.59 & 0.59 & 0.57 & 0.48 & 0.37 & 0.38 \\
\hline & Т 66 & 0.38 & 0.52 & 0.61 & 0.58 & 0.64 & 0.51 & 0.37 & 0.39 \\
\hline & K E1 & 0.33 & 0.47 & 0.57 & 0.56 & 0.61 & 0.52 & 0.32 & 0.40 \\
\hline & $F$-Probability & 0.13 & 0.43 & 0.51 & 0.55 & 0.18 & 0.28 & 0.24 & 0.53 \\
\hline & S.E.D & 0.03 & 0.04 & 0.03 & 0.04 & 0.04 & 0.03 & 0.03 & 0.02 \\
\hline & L.S.D & 0.06 & 0.09 & 0.07 & 0.07 & 0.07 & 0.05 & 0.06 & 0.04 \\
\hline
\end{tabular}

TABLE 7: Optimum times for discriminating crops for different planting times.

\begin{tabular}{|c|c|c|}
\hline Weeks from September 1 & Spectrally dominant crop & Crop area $(\mathrm{A})$ \\
\hline $0-9$ & September (s) & $A=A_{\mathrm{s}}$ only \\
\hline $10-12$ & September (s) + October (o) & $A=A_{\mathrm{s}}+A_{\mathrm{o}}\left(A_{\mathrm{s}}>A_{\mathrm{o}}\right)$ \\
\hline $13-15$ & September (s), October (o), and November (n) & $\begin{array}{c}A=A_{\mathrm{s}}+A_{\mathrm{o}}+A_{\mathrm{n}} \\
\mathrm{NDVI}_{\mathrm{o}}>\mathrm{NDVI}_{\mathrm{s}}>\mathrm{NDVI}_{\mathrm{n}}\end{array}$ \\
\hline $16-18$ & October (o) and November (n) & $\begin{array}{c}A=A_{\mathrm{o}}+A_{\mathrm{n}} \\
\mathrm{NDVI}_{\mathrm{o}} \geq \mathrm{NDVI}_{\mathrm{n}}\end{array}$ \\
\hline $18-20$ & October (o), November (n), and December (d) & $\begin{array}{c}A=A_{\mathrm{o}}+A_{\mathrm{n}}+A_{\mathrm{d}} \\
\left(\mathrm{NDVI}_{\mathrm{o}}=\mathrm{NDVI}_{\mathrm{n}}\right) \geq \mathrm{NDVI}_{\mathrm{d}}\end{array}$ \\
\hline $20-22$ & November (n) and December (d) & $\begin{array}{c}A=A_{\mathrm{o}}+A_{\mathrm{n}}+A_{\mathrm{d}} \\
\mathrm{NDVI}_{\mathrm{o}}=\mathrm{NDVI}_{\mathrm{n}}=\mathrm{NDVI}_{\mathrm{d}}\end{array}$ \\
\hline $23-26$ & December $(\mathrm{d})$ & $\begin{array}{c}A=A_{\mathrm{d}} \\
\mathrm{NDVI}_{\mathrm{d}} \text { only }\end{array}$ \\
\hline
\end{tabular}

One has the following:

(1) $A$ : crop area,

(2) $A_{\mathrm{s}}, A_{\mathrm{o}}, A_{\mathrm{n}}$, and $A_{\mathrm{d}}$ : areas for the September, October, November, and December crops,

(3) $\mathrm{NDVI}_{s}, \mathrm{NDVI}_{\mathrm{o}}, \mathrm{NDVI}_{\mathrm{n}}$, and NDVI $\mathrm{d}$ : NDVI for the September, October, November, and December crops.

discriminating the September-October planted tobacco from the nonirrigated November-December tobacco. Although the December crop remained in the field beyond 24 weeks after the September 1 planting date, spectral confusion due to weeds, other crops, and even sucker regrowth from earlier planted crop could make its separation difficult.

Using time serial NDVI data with agricultural calendars, tobacco planted on different planting dates can be separated 
and each crop area can be separately possibly determined using remote sensing and agronomic techniques.

The temporal windows for planting date separation established in this research have to be tested in future tobacco crop area forecast research. More work is also needed to establish the relationship between the Cropscan MSR 5 reflectance and reflectances for selected satellite platforms like Modis, Landsat 5, and Landsat TM, which have been used for the same purpose over large areas in other crops [36].

\section{Conflict of Interests}

The authors declare that there is no conflict of interests regarding the publication of this paper.

\section{Acknowledgments}

The authors are grateful to the Tobacco Research Board/ Kutsaga Research Station for funding this series of experiments on "developing flue cured tobacco crop area and yield forecasting models using remote sensing and agronomic techniques." The Tobacco Research Board is a research Institution and the first author of the paper is registered D.Phil. student with the University of Zimbabwe, with the other three as supervisors. This paper is the third of five papers developed from the five objectives of the D.Phil. studies. The TRB strives to publish all research works that are carried out, not for financial gain.

\section{References}

[1] F. Su, L. Fu, H. Chen, and L. Hong, "Balancing nutrient use for flue-cured tobacco," Better Crops, vol. 90, no. 4, pp. 23-25, 2006.

[2] C. T. MacKown, S. J. Crafts-Brandner, and T. G. Sutton, "Earlyseason plant nitrate test for leaf yield and nitrate concentration of air-cured burley tobacco," Crop Science, vol. 40, no. 1, pp. 165$170,2000$.

[3] G. A. Blackburn, "Remote sensing of forest pigments using airborne imaging spectrometer and LIDAR imagery," Remote Sensing of Environment, vol. 82, no. 2-3, pp. 311-321, 2002.

[4] O. Mutanga, Hyperspectral remote sensing of tropical grass quality and quantity [Ph.D. thesis], Wageningen University. ITC, Wageningen, The Netherlands, 2004.

[5] J. G. Ferwerda, Measuring and mapping the variation of chemical components in foliage using hyperspectral remote sensing [Ph.D. thesis], Wageningen University. ITC, Wageningen, The Netherland, 2005.

[6] E. Boegh, H. Soegaard, N. Broge et al., "Airborne multispectral data for quantifying leaf area index, nitrogen concentration, and photosynthetic efficiency in agriculture," Remote Sensing of Environment, vol. 81, no. 2-3, pp. 179-193, 2002.

[7] A. A. Gitelson and M. N. Merzlyak, "Remote sensing of chlorophyll concentration in higher plant leaves," Advances in Space Research, vol. 22, no. 5, pp. 689-692, 1998.

[8] T. M. Blackmer and J. S. Schepers, "Use of a chlorophyll meter to monitor nitrogen status and schedule fertigation for corn," Journal of Production Agriculture, vol. 8, no. 1, pp. 56-60, 1995.

[9] P. M. Hansen and J. K. Schjoerring, "Reflectance measurement of canopy biomass and nitrogen status in wheat crops using normalized difference vegetation indices and partial least squares regression," Remote Sensing of Environment, vol. 86, no. 4, pp. 542-553, 2003.

[10] G. P. Asner, "Biophysical and biochemical sources of variability in canopy reflectance," Remote Sensing of Environment, vol. 64, no. 3, pp. 234-253, 1998.

[11] C. S. T. Daughtry, C. L. Walthall, M. S. Kim, E. B. De Colstoun, and J. E. McMurtrey III, "Estimating corn leaf chlorophyll concentration from leaf and canopy reflectance," Remote Sensing of Environment, vol. 74, no. 2, pp. 229-239, 2000.

[12] O. W. Liew, P. C. J. Chong, B. Li, and A. K. Asundi, "Signature optical cues: emerging technologies for monitoring plant health," Sensors, vol. 8, no. 5, pp. 3205-3239, 2008.

[13] D. Haboudane, J. R. Miller, E. Pattey, P. J. Zarco-Tejada, and I. B. Strachan, "Hyperspectral vegetation indices and novel algorithms for predicting green LAI of crop canopies: modeling and validation in the context of precision agriculture," Remote Sensing of Environment, vol. 90, no. 3, pp. 337-352, 2004.

[14] S. L. Osborne, J. S. Schepers, D. D. Francis, and M. R. Schlemmer, "Detection of phosphorus and nitrogen deficiencies in corn using spectral radiance measurements," Agronomy Journal, vol. 94, no. 6, pp. 1215-1221, 2002.

[15] S. Graeff, D. Steffens, and S. Schubert, "Use of reflectance measurements for the early detection of $\mathrm{N}, \mathrm{P}, \mathrm{Mg}$, and $\mathrm{Fe}$ deficiencies in Zea mays L," Journal of Plant Nutrition and Soil Science, vol. 164, pp. 445-450, 2001.

[16] S. Graeff and W. Claupein, "Quantifying nitrogen status of corn (Zea mays L.) in the field by reflectance measurements," European Journal of Agronomy, vol. 19, no. 4, pp. 611-618, 2003.

[17] J. K. Aase, A. B. Frank, and R. J. Lorenz, "Radiometric reflectance measurements of northern great plains rangeland and crested wheatgrass pastures," Journal of Range Management, vol. 40, no. 4, pp. 299-302, 1987.

[18] F. Stocks, Tobacco Production in Zimbabwe, Nehanda Publishers (Pvt), Harare, Zimbabwe, 1994.

[19] D. Magadlela, "A smoky affair: challenges facing some smallholder burley tobacco producers in Zimbabwe," Zambezia, vol. 24, no. 1, pp. 13-30, 1987.

[20] R. D. Jackson, P. N. Slater, and P. J. Pinter Jr., "Discrimination of growth and water stress in wheat by various vegetation indices through clear and turbid atmospheres," Remote Sensing of Environment, vol. 13, no. 3, pp. 187-208, 1983.

[21] J. U. H. Eitel, R. F. Keefe, D. S. Long, A. S. Davis, and L. A. Vierling, "Active ground optical remote sensing for improved monitoring of seedling stress in nurseries," Sensors, vol. 10, no. 4, pp. 2843-2850, 2010.

[22] R. Benedetti and P. Rossini, "On the use of NDVI profiles as a tool for agricultural statistics: the case study of wheat yield estimate and forecast in Emilia Romagna," Remote Sensing of Environment, vol. 45, no. 3, pp. 311-326, 1993.

[23] E. Svotwa, B. Maasdorp, A. Murwira, and A. Masuka, "Selection of optimum vegetative indices for the assessment of tobacco float seedlings response to fertilizer management," ISRN Agronomy, vol. 2012, Article ID 450473, 10 pages, 2012.

[24] Y. Curnel and R. Oger, "Agrophenology indicators from remote sensing: state of the art," in ISPRS Archives XXXVI-8/W48 Workshop Proceedings: Remote Sensing Support to Crop Yield Forecast and Area Estimates, pp. 31-38, Stresa, Italy, NovemberDecember 2006.

[25] C. J. Tucker, "Red and photographic infrared linear combinations for monitoring vegetation," Remote Sensing of Environment, vol. 8, no. 2, pp. 127-150, 1979. 
[26] Tobacco Research Board (TRB), Flue Cured Tobacco Recommendations, TRB, Harare, Zimbabwe, 2010.

[27] U. Mazarura and C. Chisango, "Effects of long term cropping systems on soil chemical properties," Asian Journal of Agriculture and Rural Development, vol. 2, no. 4, pp. 632-640, 2012.

[28] T. A. Fasheun and E. E. Balogun, "Some spectral signatures of grain amaranthus (Amaranthus cruentus, L)," International Journal of Remote Sensing, vol. 13, no. 11, pp. 2009-2015, 1992.

[29] G. Peng, L. Deng, W. Cui, T. Ming, and W. Shen, "Remote sensing monitoring of tobacco field based on phenological characteristics and time series image-A case study of chengjiang county, Yunnan Province, China," Chinese Geographical Science, vol. 19, no. 2, pp. 186-193, 2009.

[30] R. C. Nageswara-Rao, J. H. Williams, M. V. K. Sivakumar, and K. D. R. Wadia, "Effect of water deficit at different growth phases of groundnut. II. Response to drought during pre-flowering phas," Agronomy Journal, vol. 80, pp. 431-438, 1988.

[31] J. M. Moore, "Irrigation: a proper technique guide to irrigating tobacco," 2010, http://www.tobaccofarmquarterly.com/.

[32] I. Gondola, "Weather conditions and nitrogen supply on ripening rate, yield and quality of flue-cured tobacco," in CORESTA Congress, Harare, Zimbabwe, 1994.

[33] R. Devndra, Y. S. Veeraj, M. U. Kumar, and K. S. K. Sastry, "Leaf area duration and its relationship to productivity in early rice cultivars," Proceedings of the National Academy of Sciences, India Section B, vol. B49, no. 6, pp. 693-696, 1983.

[34] M. Saleem, M. Maqsood, and M. Ul-Hassan, "Leaf area duration and total dry matter responses of cotton to integrated plant nutrition and irrigation scheduling," Crop Management, vol. 8, no. 1, 2009.

[35] D. Jiang, N.-B. Wang, X.-H. Yang, and J.-H. Wang, "Study on the interaction between NDVI profile and the growing status of crops," Chinese Geographical Science, vol. 13, no. 1, pp. 62-65, 2003.

[36] C. Yang, J. H. Everitt, and J. M. Bradford, "Using high resolution QuickBird satellite imagery for cotton yield estimation," in ASAE Annual International Meeting 2004, pp. 893-904, paper number 041119, August 2004. 


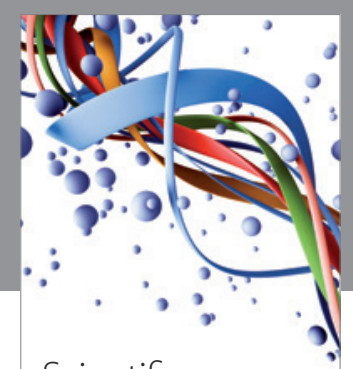

Scientifica
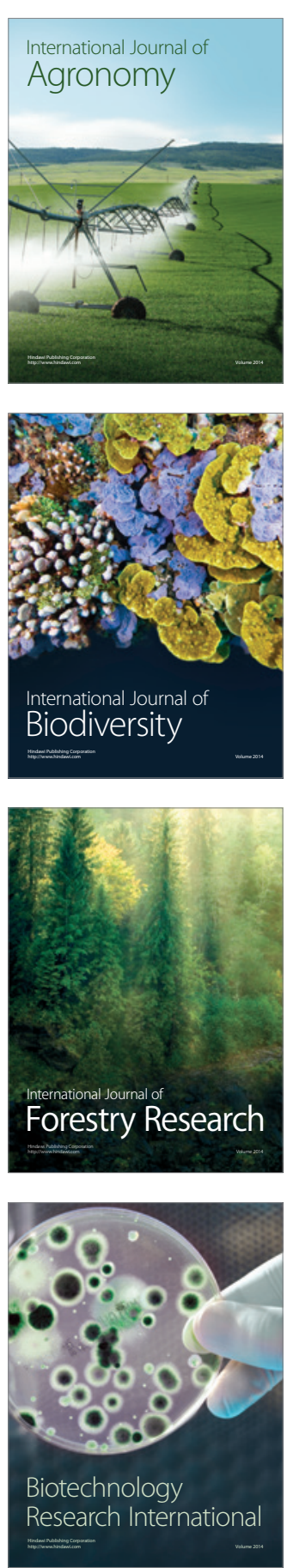
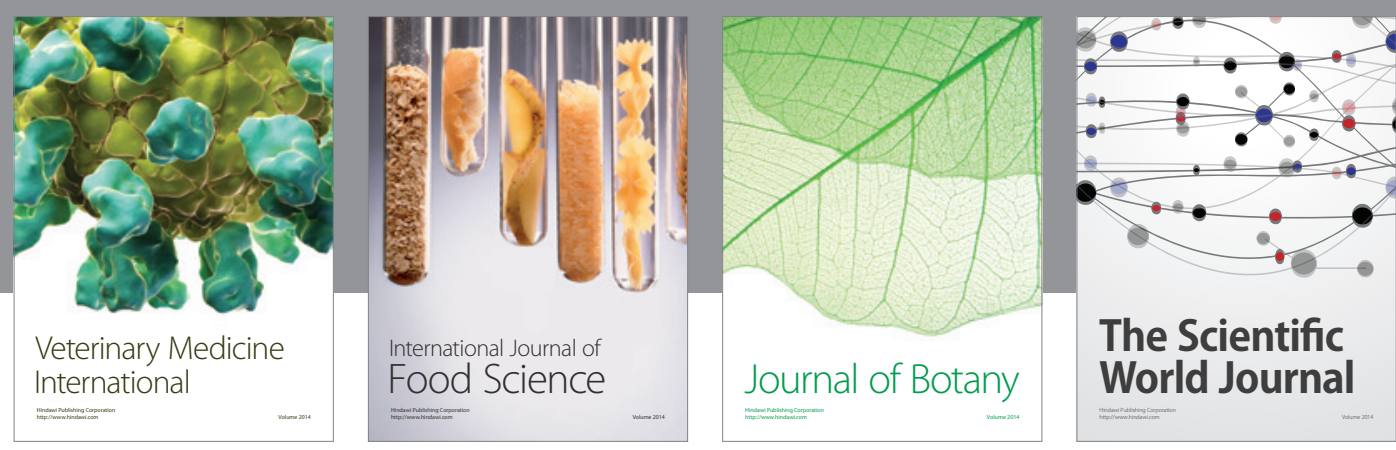

The Scientific World Journal
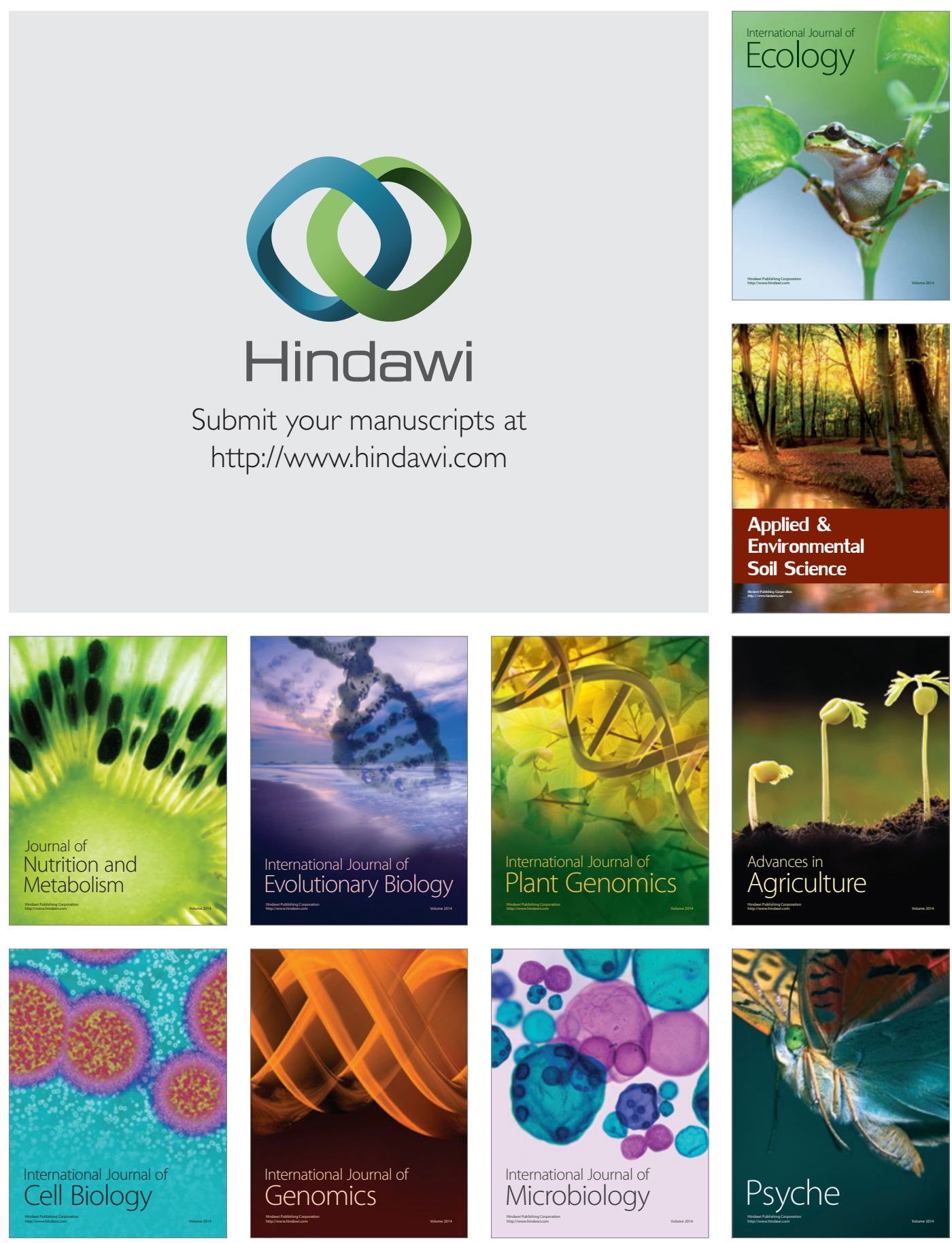